\title{
Nieostrość z perspektywy teorii komunikacji i badań normalności
}

\section{Wstęp}

Powodem poniższych rozważań była fotografia w ogóle oraz niektóre moje zdjęcia pokazywane swego czasu na wystawach - zdjęcia, które zaklasyfikować można jako nieostre, niewyraźne lub (chcąc być złośliwym albo podkreślić swą eksperckość i władzę interpretacyjną) nieudane. Niemniej jednak akurat tego typu fotografie stawały się często na wernisażach lub przy przygotowaniu wystaw przedmiotem rozmów, budząc większą ciekawość niż te „ostre”, które czasem też zdarza mi się wykonywać. Tego typu podejście do zdjęć wskazuje na to, że dają one widzowi szersze, gdyż już na wstępie nieokreślone możliwości widzenia w nich „czegoś” i ich interpretacji, tworząc w ten sposób punkt wyjścia dla konstruowania własnych historii. Zdają się tym samym mieć jakąś specyficzną wartość dla komunikacji, gdyż niezależnie od tego, czy w ramach procedur normalizacyjnych takie fotografie klasyfikowane są jako „nieostre”, czy generują skojarzenia i kreatywność, charakteryzuje je szeroko zróżnicowana gama możliwych nawiązań oraz pewien naddatek znaczenia, które są w stanie uruchomić i utrzymywać w ruchu komunikację.

Z perspektywy systemowo-konstruktywistycznej teorii komunikacji wyjść można z założenia, że nieostrość jako kategoria komunikacji wspiera leżący u podstaw społeczeństwa mechanizm negocjowania znaczeń poprzez generowanie szerokiej gamy ofert komunikacyjnych (wypowiedzi) oraz możliwych nawiązań do nich. $\mathrm{Na}$ tym tle i w obliczu tak istotnej roli tego zjawiska warto zająć się nieostrością bliżej, wychodząc od poziomu teorii, a następnie przejść do badań empirycznych. 


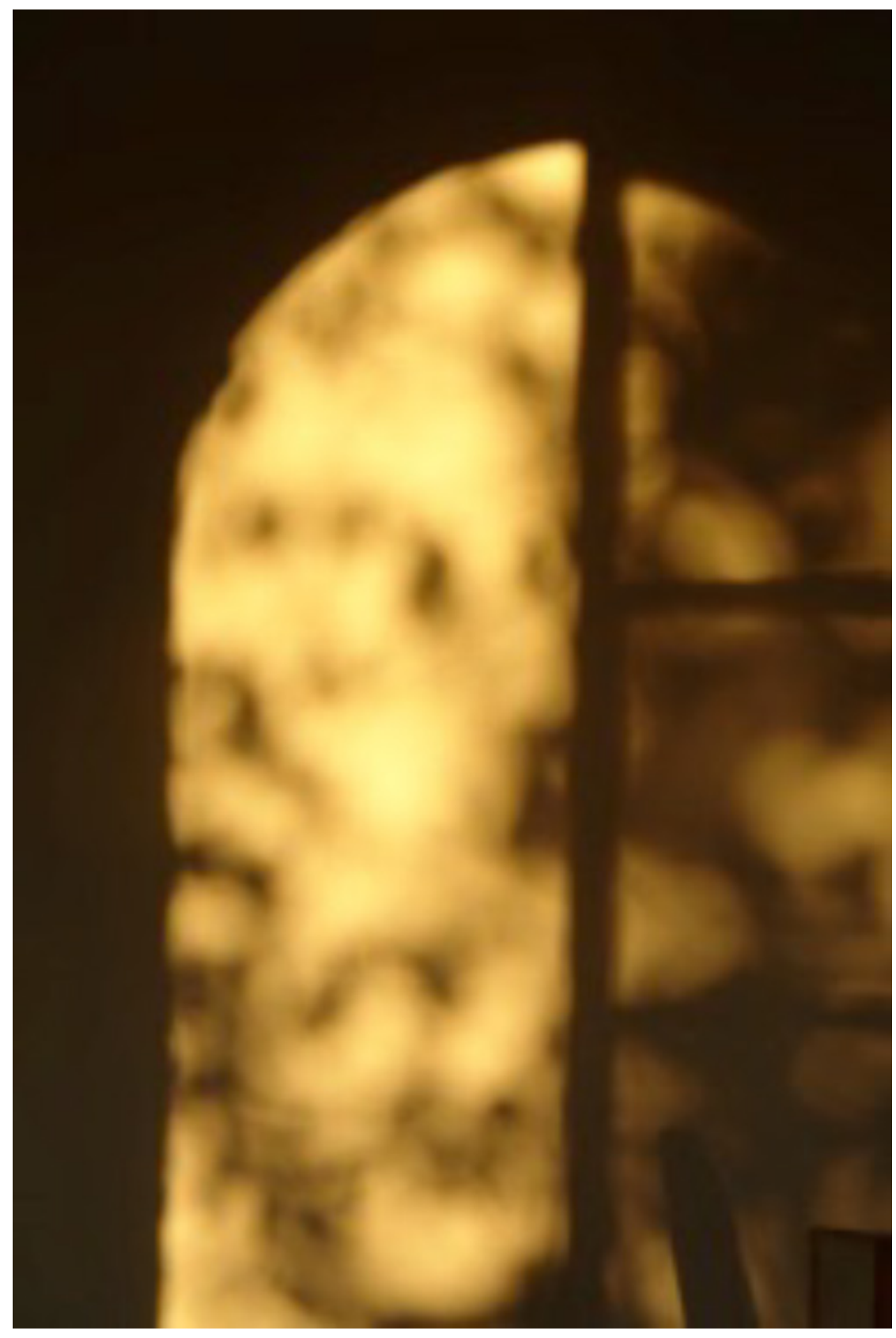

Ilustracja 1. Coś, gdzieś, kiedyś... ${ }^{1}$ (fot. Annette Siemes)

Źródło: archiwum autorki.

1 Wybrane reakcje w ramach opisanego niżej badania eksploracyjnego: za oknem / pragnienie starości / drabina / pożegnanie / tajemnica. 
Nieostrość prezentuje się na różne sposoby - nie tylko w zależności od dyscypliny, w ramach której jest rozpatrywana, lecz także w odniesieniu do badanych materiałów. Poniższy tekst poddaje zagadnienie analizie w kontekście teorii komunikacji oraz badań normalności, zwracając uwagę na aspekt funkcjonalny kategorii nieostrości w komunikacji właśnie. Aspekt ten jest o tyle istotny, że w wymiarze funkcjonalnym nieostrość może (ale nie musi) manifestować się $w$ formie dosłownych odniesień w wypowiedziach, to znaczy poprzez pojawianie się stów „nieostre”, "nieostrość" itp. Stanowi to co prawda także konstrukt, do którego na poziomie werbalnym nawiązać można wprost, jednak nawet wtedy operuje się określonym zestawem przesłanek normalnościowych, umożliwiających dopiero określanie czegoś jako „będącego nieostrym”. Oprócz tego typu bezpośredniego nawiązania nieostrość może ponadto stanowić konceptualną przesłankę wypowiedzi, nie pojawiając się w nich dosłownie.

Analizowana tu wielkość wyznaczona jest zatem przez funkcję i charakter przesłanek normalnościowych, a jej funkcjonowanie w komunikacji manifestuje się tylko potencjalnie, a niekoniecznie poprzez werbalne stwierdzenie (komunikacyjne nawiązanie do) braku dokładnego określenia czegoś. Co ciekawe, owo „coś” (to, co klasyfikowane jest jako nieostre) musi z kolei być określane w takim stopniu, by w ogóle móc do niego nawiązać i stwierdzić jego nieostrość czy wskazać choćby kierunek nawiązań. W tle sytuuje się więc lub zgoła musi się sytuować przesłanka istnienia „ostrego" prototypu (oryginału, poprawnej realizacji, wyrazistości itp.), nawet jeśli go nie znamy lub nie wiemy, jak on dokładnie wygląda. W tym punkcie napotykamy zatem kwestię przesłanek normalnościowych w komunikacji, obecnych w tle każdej wypowiedzi i każdego nawiązania do "czegoś”2.

Aby roboczo ustalić obszar tego typu analiz, jako „nieostre” w komunikacji określić możemy więc to, co jest w jakiś sposób klasyfikowane jako „nie do końca określone” lub „niejasne” i do czego odnosimy się rekursywnie na podstawie wyobrażenia dotyczącego „do końca” określonej, ostrej, wyraźnej wersji, stanowiącej niezbędną przesłankę konstatacji nieostrości, pojawiającej się (eksplicytnie lub implicytnie) wraz z wypowiedzią jako przesłanka normalności. W ramach przyjętej tu perspektywy jako komunikacyjne synonimy nieostrości (w przypadku dosłownych manifestacji) potraktować można między innymi takie pojęcia, jak „nieokreśloność”, „niejasność”, „brak wyrazistości”, „mglistość” czy też fuzziness. Innym wskaźnikiem (swego rodzaju indeksem) nieostrości w komunikacji (w przypadku pośrednich odniesień) mogą być ponadto elementy wypowiedzi wskazujące na brak dokładniejszego określenia lub potrzebę dookreślenia danego $x$, rozumianego jako założony przez dwie strony obiekt odniesienia. Tutaj otwiera się

2 Szerzej o normalności w komunikacji zob. Siemes, 2015. 
jeszcze jeden ciekawy wymiar. W tym kontekście bowiem nieostre wizualizacje lub werbalizacje można by (z perspektywy semiotycznej, a konkretnie typologii znaków Charlesa Sandersa Peirce'a - zob. Peirce, 1931-1958; Fleischer, 2020: 11-40), traktować jako indeks właśnie, przy czym ostra, wyraźna realizacja stanowiłaby (w wizualizacjach) typowy znak ikoniczny lub (w werbalizacjach) typowy znak symboliczny, natomiast nieostra, rozmyta wersja byłaby indeksem, czyli występowałaby w relacji wskazywania w myśl hasła - indeks wskazuje na ikonę/symbol. Natomiast „swego rodzaju indeksem” znak taki byłby właśnie poprzez odmiennie realizowaną generatywną dla niego relację wskazywania; w typowych realizacjach indeks wskazuje na coś spoza obszaru znaków, tutaj natomiast na inny znak, pozostaje zatem w obrębie systemu, tworząc relacje międzyznakowe czy wewnątrzsystemowe, usieciowiając wszystkie trzy klasy znaków.

W odniesieniu do fotografii wyróżnia się różne formy nieostrości ${ }^{3}$, które, historycznie rzecz biorąc, zostały „odkryte” lub wypracowane jako nowa forma wyrazu, a następnie stosowane były na wiele sposobów w różnych kontekstach. Zwłaszcza w początkach fotografii formy te podlegały debatom nawiązującym zarówno do malarstwa i zasadniczo sztuki oraz możliwości i roli fotografii na tym obszarze, jak i do szerszych kwestii estetycznych i poznawczych (zob. Ullrich, 2002). W rozwoju fotografii nieostrość rozumiana była między innymi jako (ponowne) zbliżenie fotografii do sztuki oraz jako środek wytwarzania „artystycznie cennych” obrazów, mających być czymś więcej niż „czystą mimesis”. W związku z tym fotografom artystycznym na przełomie XIX i XX wieku chodziło także o to, „czy byliby w stanie w podobnej mierze odejść od »normalnego« obrazu tego, co się widzi, jak czynią to malarze lub graficy" (Ullrich, 2002: 26), a nie jedynie obsługiwać mechanicznie odzwierciedlające rzeczywistość medium.

Ujmując rzecz z tej perspektywy, nieostrość nie tylko wydaje się ściśle związana z wymiarem wizualnym, lecz także (lub nawet przede wszystkim) z obszarem sztuki jako takiej. Zajmując się historią nieostrości na obszarze wizualnym Wolfgang Ullrich podkreśla jednak, że w odniesieniu do obrazów pojęcie nieostrości staje się aktualne (także w sensie jego aktualizacji w komunikacji) dopiero od momentu pojawienia się fotografii:

W każdym wypadku w ostatniej dekadzie XIX wieku „nieostrość” stała się kategorią oceny obrazów fotograficznych, a opozycyjną parę „ostre” i „nieostre” znaleźć można od tego czasu zdecydowanie częściej w tym kontekście niż przy opisie zjawisk zmysłu wzroku lub kwalifikowaniu wydolności przypominania sobie [czegoś - przyp. A.S.] (Ullrich, 2002: 27).

3 Należą do nich na przykład nieostrość ruchu, efekt zmiękczenia oraz efekty nieostrości wynikające z prześwietlenia. 
Można co prawda, idąc za Ullrichem, datować początek historii nieostrości w kontekście wizualnym już przed epoką fotografii, odnosząc się na ogół do „nurtu nieostrości" w malarstwie (np. u Williama Turnera) lub do impresjonizmu w szczególności, jednak mniej sensowne jest według niego cofanie się poza XIX wiek, gdyż „wtedy zaczynamy mieć do czynienia z innymi kontekstami ideowymi, w których nie było jeszcze miejsca dla tego, co nieostre" (Ullrich, 2002: 27), w sensie jego konceptualizacji w opozycji do tego, co ostre, produkowanego za pomocą technicznej aparatury wspomagającej przy odzwierciedlaniu realnego (wizualnego) świata.

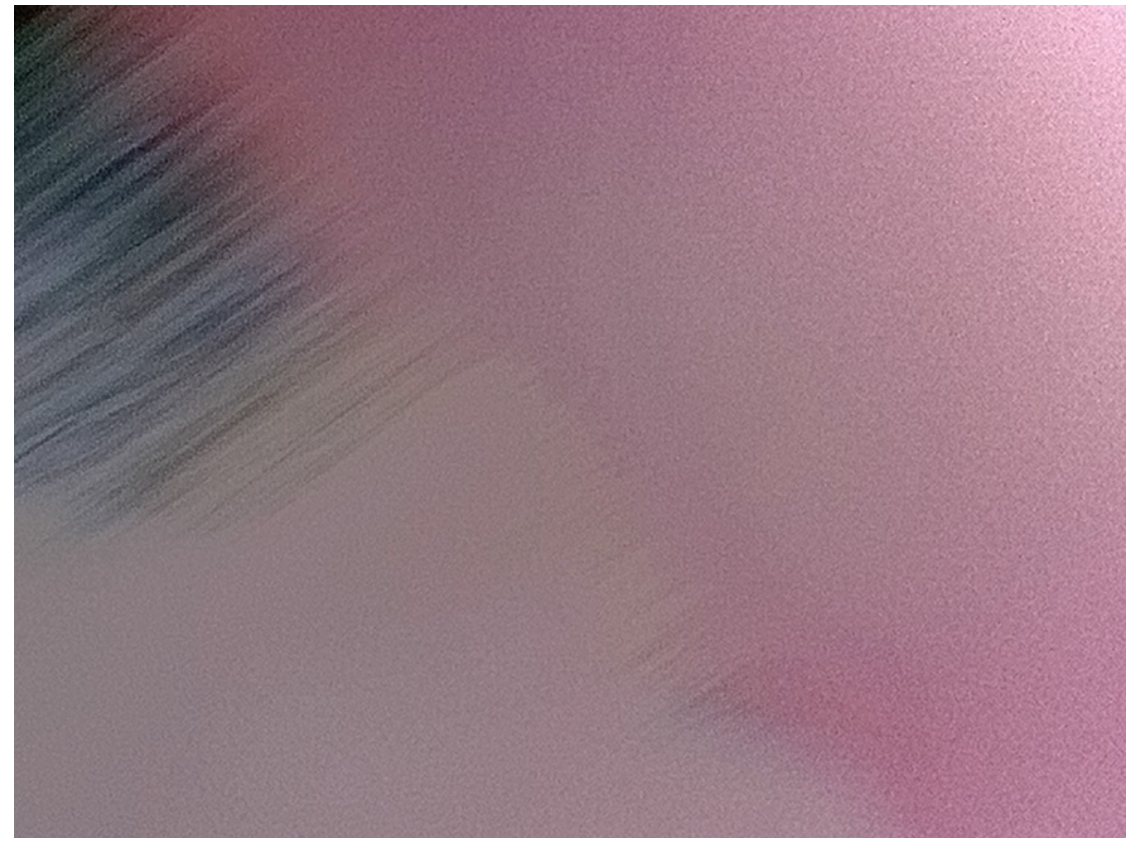

Ilustracja 2. rzęsa / poranek / rysunek / pejzaż-haiku / impresjonizm... (fot. Annette Siemes) Źródło: archiwum autorki.

Już zatem w perspektywie skupiającej się na wizualności istotny staje się wymiar komunikacyjny, a co za tym idzie - pytanie o charakter oraz rolę nieostrości jako kategorii komunikacji: czy to w roli i funkcji konstruktu, czy związanego z systemem przesłanek konceptu, czy też jako podstawa dla uruchamiania procesu komunikacji. Nieostrość może więc z jednej strony być (i jest) aktywowana na różne sposoby w danym czasie oraz kontekście historycznym (jako konstrukt i koncept), a z drugiej strony pełni funkcję ogólną w komunikacji jako punkt wyjścia dla produkcji wypowiedzi. Na jej fundamentalną rolę wskazuje także to, że zagadnienia 
związane z nieostrością i nieokreślonością stanowią przedmiot refleksji wielu dyscyplin naukowych, a w myśli filozoficznej pojawiają się już od czasów starożytnych4.

Z uwagi na fotografię amatorską ${ }^{5}$, która aktualnie, w obliczu powszechnie dostępnych możliwości robienia zdjęć (a raczej produkcji obrazów) cyfrowych staje się niemal naturalnym elementem życia codziennego, nieostrość widziana jest przede wszystkim w dwóch przeciwstawnych kategoriach: albo stanowi wadę, której należy unikać, albo uznawana jest za środek stylistyczny nadający obrazowi atmosferę i świadczący o jego autentyczności (często pozornej, gdyż „dodawanej” post factum za pomocą stosownych narzędzi). Tę dualistyczną kategoryzację potwierdzają już wyniki eksploracyjnego wyszukiwania fraz typu „nieostre obrazy/zdjęcia” oraz „nieostrość, fotografia” w zasobach internetu. Na pierwszych miejscach listy wyszukiwań pojawiają się bowiem przede wszystkim porady praktyczne dotyczące unikania i retuszowania lub dodawania nieostrości, nazwy odpowiednich programów i aplikacji oraz instrukcje stosowania tego typu narzędzi ${ }^{6}$. Ciekawe dla badań komunikacji i kwestii normalności są pojawiające się wtedy paradoksalne sformułowania, w których radzi się, jak wygenerować „fotograficznie poprawną nieostrość", ilustrujące specyficzny charakter konstruktu nieostrości w wymiarze komunikacyjnym (zob. Computerwissen, 2017).

Nieostrość jako kategoria komunikacji wyróżnia się zatem tym, że nie jest wielkością budowaną na podstawie jednolitego systemu przesłanek łączonych w myśl reguł logiki, lecz funkcjonującą i uzyskującą znaczenie oraz sens dopiero na tle kontekstów wprowadzanych do komunikacji wraz z wypowiedzią, w której kategoria nieostrości jest aktualizowana. Przy tym możliwość pojawienia się sprzeczności wynikających z różnych, niekiedy wykluczających się wzajemnie definicji nieostrości, nie jest cechą dewaluującą ją komunikacyjnie, lecz dodającą jej wartości (przynajmniej z punktu widzenia komunikacji). W sytuacji pojawienia się takich sprzeczności i niejasności debatować można bowiem o tym, czym jest nieostrość, jak ją określić (= oksymoron), jaki ma ona wpływ na potencjalny odbiór danego $x$, kto ma rację itd. Każda z opcji (ostre, nieostre, atmosfera, autentyczność itp.) może

4 Jednym ze standardowych przykładów w tym zakresie jest paradoks kopca (też: stosu) lub łysego, ilustrujący niemożliwość wyznaczenia jednoznacznej granicy, od której dane $x$ (np. liczba ziaren piasku lub włosów) może być nazwane kopcem, względnie łysym. „Zagadnienie nieostrości jest związane z paradoksem stosu, zwanym od greckiego rzeczownika "soros» 0znaczającego »stos» paradoksem sorites" (Kukołowicz, 2018: 11; zob. też Doboszyńska-Markiewicz, 2015: 139).

5 Określenie, które (jak każde inne konstruowane według tego wzoru, np. „fotografia profesjonalna”) zaliczać można do zabiegów normalizacyjnych w komunikacji.

6 Dla rozszerzenia pola obserwacji wyszukiwanie było prowadzone w dwóch językach (polskim i niemieckim) wyszukiwarką www. startpage.com, 23.10.2019 roku. Przykładowe egzemplifikacje (tytuły wpisów na liście wyników): 12 porad jak uniknąć nieostrego zdjęcia; Ostre - nieostre, czyli o sztuce (nie)ostrzenia fotografii; Jak robić zawsze ostre zdjęcia; Unscharfe Bilder: 13 Ursachen und Tipps, wie du es verhinderst [Nieostre zdjęcia: 13 powodów i wskazówek, jak możesz tego uniknąc]; Unscharfe Bilder scharf machen: Diese Möglichkeiten hast du [Przerabiać zdjęcia nieostre na ostre: Masz takie możliwości]; 8 Gründe für unscharfe Fotos und was du dagegen tun kannst [8 przyczyn nieostrych zdjęć oraz co możesz przeciwko temu zrobic]. 
w ten sposób być punktem wyjścia do dalszych debat, a powstające w ten sposób wypowiedzi mogą służyć jako materiał do badań dotyczących zarówno konstruktu, jak i konceptu nieostrości (autentyczności itd.) oraz ich funkcji w komunikacji.

Przypadek „autentyczności” ilustruje liczne powiązania między „nieostrością” a innymi wyrazami, niemającymi z nią na poziomie semantycznym zbyt wiele lub zgoła nic wspólnego. Autentyczność (w powiązaniu z nieostrością) pojawia się zarówno w przytoczonym wyżej kontekście codziennej, amatorskiej produkcji zdjęć, jak i w ramach omawiania zagadnień związanych z systemem mediów i pracą dziennikarską czy też z obszarem sztuki. W odniesieniu do zdjęć amatorskich zwraca się przy tym uwagę na dodawanie autentyczności przez nieostrość: „Dlaczego nieostre, rozmyte motywy oraz rezygnacja z fotorealistycznych realizacji dają obrazowi zwiększoną autentyczność?" (Asmani, za Freitag i wsp., 2018: 8). Nieostrość widziana jest wtedy jako „środek stylistyczny stosowany w sztukach plastycznych oraz w mediach masowych [...], aby wyabstrahować dzieło, pozwalając mu tym samym na autentyczniejsze oddziaływanie" (Asmani, za Freitag i wsp., 2018: 8). Jednak czym „jest” nieostrość w komunikacji poza wymiarem semantycznym, dotyczącym samego słowa/konstruktu oraz jego połączeń z innymi wyrazami, to znaczy jaką funkcję pełni na tle procesu produkcji ofert komunikacyjnych (wypowiedzi) oraz nawiązań do nich?

\section{Nieostrość jako cecha i właściwość}

Na podstawie referowanych wyżej kategoryzacji na temat wymiaru wizualnego, nieostrość (odnosząc się do niej eksplicytnie i werbalnie bądź nie) może być widziana jako element, który można dodać lub usunąć. Oznacza to też, że zakładany jest obraz „jako taki”, na który nałożyć można nieostrość lub ją niwelować, aby osiągnąć stosowny cel. Ullrich wskazuje na dualizm leżący u podstaw takiej konceptualizacji, według której obrazy klasyfikowane mogą być jako „obiektywne” z jednej strony lub „artystyczne” z drugiej i która stosowana była już w historii na przełomie XIX i XX wieku (Ullrich, 2002: 26). W obliczu wielu notorycznie wykorzystywanych możliwości obróbki obrazów za pomocą programów do edycji zdjęć, aplikacji w urządzeniach mobilnych itp. można zadać pytanie o to, czy ten konceptualny podział nie uległ w międzyczasie zmianie. Jest to dość ciekawy aspekt dla badań komunikacji oraz normalności i jej przesłanek (dotyczących tego, co zakładane jest w danym czasie i kontekście jako oczywiste, co jest akceptowane przez „większość” lub „wszystkich”, co jest zwykłe, niewarte mówienia o tym, czyli normalne właśnie). Czy w ogóle i w jakim stopniu zdjęcia widziane są dzisiaj jeszcze 
jako medium odzwierciedlające lub takie, które powinno odzwierciedlać rzeczywistość? Czy też koncepcja dotycząca tej formy medialnej, jej roli i możliwości podlegała może zasadniczym zmianom w obliczu szeroko rozwiniętych zabiegów obróbki obrazu, do których przy wykorzystaniu technologii cyfrowej typu smart często dochodzi już w momencie „wykonywania” zdjęcia? Jak wpływa to na postrzeganie innych form wizualnych?

Wracając do kwestii nieostrości: traktowanie jej jako elementu, który można usunąć z obrazu lub też do niego dodać, oznacza również, że nieostrość (w tej perspektywie) nie jest widziana jako inherentna właściwość świata, lecz jako coś, co powstaje z powodu technicznej niedoskonałości urządzeń, braku umiejętności ich obsługiwania, jako coś, co (za pomocą techniki) może być dodawane, czego należy unikać lub co należy usuwać; świat wyjściowy natomiast jest/musi być (w tej konceptualizacji) „ostry”, dokładny i jednoznaczny. Nieostrość byłaby wtedy co najwyżej punktem wyjścia procesu poznawczego w relacji do zasadniczo ostrego świata i precyzyjnie odwzorowanej rzeczywistości. W tej sytuacji można zadać pytanie: „A co, jeśli jest na odwrót albo po prostu inaczej?”.

Jak nietrudno zauważyć, kiedy zajmujemy się nieostrością z punktu widzenia technologii i jej możliwości, dochodzimy przeważnie do również technicznych rozróżnień, u podstaw których leży przesłanka produkująca wymóg opisywania świata według dyskretnych, jedno-jednoznacznych kryteriów (por. szerzej Bauer, 2018) ${ }^{7}$. Także w publikacjach nieograniczających się tylko do technologii nieostrość bywa charakteryzowana według takiej dychotomii, to znaczy na mocy przesłanki, iż ostrość i dokładność to „wyznaczony przez naturę rzeczy” punkt wyjścia. Kiedy mowa o nieostrości jako braku jednoznaczności (zob. Freitag i wsp., $\left.2018^{8}\right)$, nie jest ona traktowana jako konstrukt, negocjowa(l)na wielkość zależna od wielu dodatkowych przesłanek w tym sensie, że wymaga najpierw (w nauce: świadomego) ustalenia pewnych podstaw konceptualnych, lecz jako kategoria mająca ostre odniesienia do realności lub przynajmniej dająca się uniknąć, kiedy pozostajemy w ramach jednej perspektywy poznawczej. Tylko w ramach takiej konceptualizacji można bowiem zadać pytanie o kwestię „obchodzenia się z bra-

7 Wyrażenie, „jedno-jednoznaczny” to ściśle zdefiniowany termin oznaczający (w uproszczeniu) zachodzenie danej (i tej samej) relacji w obie strony: od $a$ do $b$ oraz od $b$ do $a$.

8 Autorzy zwracają także uwagę na różnice dotyczące tego, jak pojęcie nieostrości jest konotowane oraz stosowane w różnych dyscyplinach naukowych. Twierdzą oni, że bez względu na konkretną definicję nieostrości musi ona (ewentualnie jej skutki) być uwzględniana w badaniach naukowych. Według nich pomijanie jej oznacza „ignorowanie różnorodności, naturalnej wariacji i tym samym zniekształcenie realności" (Freitag i wsp., 2018: 11). Pojęcie realności wskazuje tu z kolei na problem poznawczy w kontekście cytowanej publikacji, która ma charakter interdyscyplinarny, gdyż dla kwestii społecznych odpowiedniejsze byłoby uwzględnienie charakteru konstruktywnego rzeczywistości społeczno-komunikacyjnej oraz innego kontekstu teoretycznego. Z punktu widzenia inżynierii istotna i adekwatna byłaby jeszzze inna perspektywa, a w naukach ścisłych sprawa przedstawia się znowu inaczej. Rzecz jest zatem relatywna w zależności od konkretnej dyscypliny i przedmiotu badań. 
kiem jednoznaczności w różnych dyscyplinach" (Freitag i wsp., 2018: podtytut publikacji oraz s. 7). Perspektywa teorii komunikacji, z punktu widzenia której nieostrość może być ujmowana jako realizacja pewnej funkcji komunikacyjnej, czyli jako wielkość zawsze już konstruowana w ramach określonych potrzeb komunikacyjnych (służących generowaniu społeczeństwa), którymi można się zajmować poznawczo, nie jest w takich konceptualizacjach przewidziana, a przynajmniej nie pojawia się eksplicytnie.

Brak uwzględniania komunikacyjnego i negocjowa(l)nego charakteru samej kategorii nieostrości może być adekwatny, kiedy chodzi o nieostrość w sensie niemożliwości dokładnego pomiaru (na przykład w naukach ścisłych). To, że w zależności od kontekstu i przyjętej perspektywy nieostrość w rzeczy samej stanowić może „wadę” czy „błąd”, nie ulega wątpliwości. Rozpatrzmy przykład inżynierii i budownictwa: kiedy coś, co z założenia miało długo stać (np. most), runie „z powodu" niedokładnych obliczeń i nieostrej prognozy dotyczącej jego wytrzymałości czy trwałości, wtedy jest to zdecydowanie niepożądany bieg rzeczy, a nieostrość - w sensie braku możliwości dokładnego określenia momentu, w którym wykorzystane do konstrukcji materiały zawodzą - stanowi poważny problem i zagrożenie, które prędzej czy później przełożą się na realne zdarzenia, jeśli nie uda się temu zapobiec. Niemniej jednak sama nieostrość nie jest powodem zawalenia się mostu, lecz materiat, który nie spełnia oczekiwań produkowanych na poziomie komunikacji. Tak więc również w takim kontekście ciekawe oraz istotne jest to, jak podchodzimy do zagadnienia nieostrości komunikacyjnie. Szczególnie ważna jest przy tym sfera interdyskursu, rozumianego jako obszar tączący różne dyskursy specjalistyczne wygenerowane na potrzeby danych subsystemów (zob. szerzej Fleischer, 2007: 249-254; Fleischer, Siemes, 2020: 20-24). W ramach interdyskursu oraz ogólnie w procesach komunikacyjnego generowania społecznych współzależności kluczową rolę odgrywają bowiem oferty komunikacyjne i nawiązywanie do nich, to znaczy negocjowanie znaczeń za pomocą języka, a szerzej znaków, a nie matematyka i obliczenia w ramach jej reguł. Ten ogólnospołeczny kontekst komunikacyjny i jego uwarunkowania mają bowiem wpływ na to, jakie decyzje są kiedy oraz w jaki sposób podejmowane przez stosowne instytucje (kiedy most, nim się zawali, zostanie odremontowany). Kwestie nauk ścisłych mogą przy tym odgrywać mniejszą rolę (co obserwować można również przy jeszcze bardziej egzystencjalnych zagadnieniach, jak na przykład katastrofa klimatyczna%).

9 Szczególnie ciekawym przypadkiem dla analiz w tym zakresie jest komunikacyjne obchodzenie się z celem zatrzymania globalnego ocieplenia na poziomie nie wyższym niż $1,5^{\circ} \mathrm{C}$, wynikającym z Porozumienia paryskiego. W medialnie zapośredniczanych komunikacjach, to znaczy w interdyskursie, pojawia się często zaokrąglona wersja progu $2^{\circ}$ i to nie zawsze z doprecyzowaniem „znacznie poniżej" (zob. Siemes, 2020: 38-40). 
Licznymi aspektami roli nieostrości zajmuje się, pod różnym kątem, również lingwistyka, niekoniecznie przyjmując perspektywę komunikacyjną w ujęciu systemowym, ale za to tym dokładniej analizując dane zagadnienie z uwagi na szeroką gamę jego manifestacji czy możliwych zastosowań oraz ich roli na tle języka. Przeglądu stanowisk dotyczących nieostrości z perspektywy lingwistyki (i filozofii) dokonała Katarzyna Doboszyńska-Markiewicz (2015):

Językoznawcy łączą nieostrość (ang. vagueness, niem. Vagheit) z pojęciem nieokreśloności semantycznej bądź referencjalnej (Pinkal, 1980), w polskiej tradycji lingwistycznej zwanej również wyznaczonościq (Topolińska, 1976), a także rozmytości kategorialnej (fuzzyness - Lakoff, 1973). [...] [Nieostrość - przyp. A.S.] w filozofii i językoznawstwie była [...] opisywana jako własność wyrażeń (i to zarówno na poziomie ich treści, jak i zakresu) lub całych kategorii, jako pojęcie logiczne, semantyczne i pragmatyczne (Doboszyńska-Markiewicz, 2015: 141, 144; wyróżnienia - K.D.-M.) ${ }^{10}$.

Nieostrość analizowana jest tutaj między innymi z perspektywy semantyki (prototypów), z uwagi na możliwości (a raczej ich brak) precyzyjnego ustalania ekstensji pojęć. Stanowi ona także ważną kwestię w lingwistyce komputerowej oraz zaproponowanym w jej kontekście podejściu fuzzy linguistics (zob. Rieger, 1996). Fuzziness ${ }^{11}$ pojawia się więc również w lingwistyce, podobnie jak pokrewne pojęcia typu fuzzy sets, mające niekiedy charakter metafor, zwłaszcza gdy są przejmowane z innych dziedzin (np. granularity z fotografii). Do lingwistycznych aspektów związanych z nieostrością można zaliczyć zarówno szersze pojęcia (jak „nieokreśloność") ${ }^{12}$, jak i węższe, dotyczące konkretnych zjawisk językowych (jak linguistic hedges) ${ }^{13}$. Te ostatnie Doboszyńska-Markiewicz określa (jak podaje za lingwistami czeskimi i rosyjskimi) jako operatory nieostrości, co jest o tyle ciekawe, że wtedy możliwe staje się znowu uwzględnianie procesualności oraz aspektu funkcjonalnego naszego zagadnienia.

10 W tym miejscu autorka wskazuje na obszerne opracowania dotyczące różnych koncepcji nieostrości: Odrowąż-Sypniewska, 2000; Kluck, 2014.

11 „W latach 70. XX wieku Lakoff opisywał nieostrość (dosłownie »rozmytoścu, ang. fuzzyness) jako własność przysługującą kategoriom semantycznym" (Doboszyńska-Markiewicz, 2015: 141; wyróżnienia - K.D.-M.).

12 „Skoro padło już nazwisko Pinkala, warto w tym miejscu przywołać jego prace o nieokreśloności, które to zjawisko jest w literaturze lingwistycznej z pewnością częściej opisywane niż nieostrość. Należałoby zatem ustalić, w jakiej relacji względem siebie oba te terminy się znajdują. Otóż Pinkal (1980; 1991) traktuje nieostrość (Vagheit) jako jeden z dwóch rodzajów nieokreśloności semantycznej (semantische Unbestimmtheit). Drugi z nich to wieloznaczność (Mehrdeutigkeit), rozumiana jako relacje homonimii i polisemii" (Doboszyńska-Markiewicz, 2015: 143; wyróżnienia - K.D.-M.).

13 „Językowe o(d)gródki (za Wierzbicka, 1999), w sensie »odgradzania się« mówiącego od odpowiedzialności za słowo przy pomocy hedges" (Doboszyńska-Markiewicz, 2015: 138). 
We wszystkich wspomnianych tu podejściach nieostrość powstaje bowiem dopiero poprzez komunikację oraz w jej ramach, w tym sensie, że jest konstruowana jako wielkość i obszar odniesień. Nawiązując do nieostrości w wypowiedziach, to znaczy mówiąc o niej (eksplicytnie) lub stosując ją (implicytnie) jako kategorię oceny czy dla oznaczenia czegoś jako niedokładne, niepewne itp., generuje się tę kategorię ( $w$ postaci konstruktu lub w wymiarze funkcjonalnym) wraz z leżącą u jej podstaw binarną opozycją „ostre/nieostre”, której granice z kolei stale można, a nawet należy (re)negocjować. Stąd też, przechodząc na poziom formalizacji procesów zawierających aspekt nieostrości, pojawia się - na przykład w lingwistyce komputerowej oraz przy opracowywaniu odpowiednich algorytmów - problem odwzorowywania elementów nieostrych w sformalizowanych strukturach wzorów. Tam, gdzie celem jest modelowanie procedur, według których pewien proces powinien się odbyć, brak możliwości ustalenia jednoznacznych relacji między elementami owego procesu stanowi przeszkodę. Rozważania na temat nieostrości to w związku z tym kluczowy problem przy tworzeniu algorytmów. Patrząc z perspektywy tych ostatnich, nieostrość jest problemem, który trzeba rozwiązać; natomiast z perspektywy ludzi i komunikacji niekoniecznie jest to problem.

Abstrahując od niekiedy zasadniczych różnic wynikających z przyjętych stanowisk, nieostrość także w tym kontekście okazuje się istotnym elementem leżącym u podstaw komunikacji, z tym że wnioski różnią się w zależności od, nierzadko sprzecznych, kontekstów interesów, zainteresowań i celów. Motywy i interesy stojące za produkcją algorytmów i rozwojem tak zwanej sztucznej inteligencji uwarunkowane są dodatkowo przez subsystem gospodarki, a to prowadzi do innych wniosków (nieostrość jako problem, który trzeba rozwiązać „dla” algorytmów) niż w kontekście badań komunikacji (nieostrość jako problem poznawczy, który pomaga nam lepiej zrozumieć komunikację). Każda dalej idąca interpretacja czy analiza poszczególnych form nieostrości zajmuje się bowiem (eksplicytnie lub implicytnie) kwestią nawiązywalności produkowanych i oferowanych przez nią w komunikacjach, to znaczy w ramach negocjowania znaczeń, kolejnych nawiązań do nawiązań ofert komunikacyjnych. Niemniej jednak zasadnicze pytania i problemy związane z funkcją nieostrości w komunikacji najczęściej się nie pojawiają (poza napomknięciem o nich w funkcji „ozdobnej” we wstępach) i nie są systematycznie analizowane teoretycznie ani badane empirycznie. Możemy zatem rozszerzyć perspektywę i możliwości poznawcze poprzez spojrzenie na temat z punktu widzenia teorii i badań komunikacji oraz operacjonalizacji zagadnienia dla potencjalnych badań. 


\section{Nieostrość jako warunek}

Patrząc z tak rozszerzonej perspektywy, przy analizie roli nieostrości w komunikacji mamy do czynienia z jeszcze istotniejszymi aspektami związanymi z procedurami normalizacyjnymi. Jako warunek utrzymania mechanizmu komunikacji w ruchu pojawia się oscylowanie pomiędzy tym, co nieokreślone, a tym, co jest (lub wydaje się) ustalone, to znaczy między negocjowaniem tego, „czym coś ma być” a konfrontacją tego z panującym standardem ${ }^{14}$. Chodzi przy tym o orientowanie się na: oczekiwania oczekiwań (w sensie S.J. Schmidta) oraz obszary normalności zakładane jako wspólne, to znaczy na to, co w mniemaniu interlokutorów z powodzeniem można zakładać jako wiążące dla obu stron. Nieostrość (niedokładność ofert komunikacyjnych) odgrywa wtedy, metaforycznie rzecz ujmując, tę samą rolę co regulator balansu w zegarku mechanicznym, prowokując czy wymuszając produkcję nawiązań do ogólnie nieostrych wypowiedzi, a tym samym utrzymując proces negocjowania znaczeń w toku.

Na poziomie języka można obserwować formy stosowania nieostrości, w których manifestuje się ten właśnie funkcjonalny aspekt. Lingwistyka sytuuje tu wyrazy typu hedges (Heckenausdrücke), to jest zwroty przysłowiowe lub przymiotnikowe, za pomocą których interlokutor zaznacza, w jakiej mierze przyporządkowuje dany obiekt do danej kategorii ${ }^{15}$. Nieostrość ujmowana jest tym samym jako wielkość stopniowalna, co z kolei zakłada skalę w tle, pracującą opozycją ostrości/nieostrości lub przyjęciem możliwości skalowania ostrości. Skupiając się „od razu" na poszczególnych elementach i aspektach języka lub na tekstach (bez ogólnej teoretycznej analizy problemu), mamy do czynienia z perspektywą, w której (dany) język ,jako taki” już istnieje i musi być zakładany jako wielkość określona (i w tym sensie ostra), przynajmniej w tej mierze, że nawiązanie do czegoś i produkcja wypowiedzi w ogóle stają się możliwe. Do tego przystaje podejście lingwistyki komputerowej, dla której „nieostrość w języku naturalnym jest najczęściej określana jako niedostateczna specyfikacja” (Freitag i wsp., 2018: 10).

14 Słowo panujący zaznaczam kursywą, gdyż raz wprowadzony standard, raz wynegocjowane obszary normalności mają tendencję samopotwierdzania się w dalszych procesach negocjacyjnych; ich zmiana wymaga większych nakładów niż ich powielanie: „[... ] powtórzenie i potwierdzenie już istniejących »pomysłów« dotyczących [danej - przyp. A.S.] normalności jest dużo bardziej prawdopodobne - produkcja wypowiedzi, dla której możemy przyjąć, że nie będzie ona odrzucona i że będzie nawiązywalna, nie tylko stanowi dużo mniej ryzykowne przedsięwzięcie, lecz wymaga też zdecydowanie mniejszego nakładu energii" (Siemes, 2013: 67).

15 W pragmatyce dla określenia semantycznej (nie)ostrości wyrazów językowych używane jest także pojęcie granularity (Granularität), pojawiające się również w koncepcjach kognitywnej analizy dyskursu (tam w sensie obecności w reprezentacjach werbalnych większej lub mniejszej liczby szczegółów - zob. Tenbrink, 2020) oraz przy informatycznej analizie tekstów języka naturalnego (zob. np. Mulkar-Mehta, Hobbs, Hovy, 2011). 
Z punktu widzenia badań komunikacji warto natomiast zwrócić uwagę na to, że negocjowanie przypisań znaczeń w ramach komunikacji ogólnie ma charakter fuzzy (rozmyty - zob. Fleischer, 2018: 31), to znaczy z zasady cechuje się nieostrością $w$ tym sensie, że powstaje w ramach nieustannego i operacjonalnie zamkniętego procesu nawiązywania do nawiązań. Analiza zagadnienia w wymiarze komunikacyjnym kieruje zatem naszą uwagę na nieostrość rozumianą nie jako właściwość (również nie lub nie tylko jako sfunkcjonalizowaną kategorię mówienia czy koncept), lecz jako funkcję sui generis. W takiej perspektywie nie pojawia się też problem jej (możliwej, a w ramach innych perspektyw potencjalnie wymaganej) konceptualizacji jako cechy, za którą idzie nie tylko możliwość, lecz nawet konieczność (konceptualna nieuniknioność) jej skalowania na tle podziału na „ostre/nieostre"16. Niemniej jednak wspomniane linguistic hedges mogą stanowić przykład wyjaśniania roli nieostrości oraz, ujmując rzecz szerzej, nieokreśloności w komunikacji z perspektywy funkcjonalnej:

Sam Lakoff definiował linguistic hedges jako wyrażenia mające za zadanie uczynić inne wyrażenia mniej ostrymi (bardziej rozmytymi) lub odwrotnie - podkreślić (wydobyć) ich ostrość: „words whose job is to make things fuzzier or less fuzzy” (Lakoff, 1973: 471). Zdaniem autora służą one do zaznaczania stopnia przynależności danego wyrażenia do jakiejś kategorii - czy jest to „okaz” prototypowy, czy raczej peryferyjny, czy tylko trochę różniący od prototypu, czy może aż tak bardzo, że trzeba go z owej kategorii wyłączyć (Doboszyńska-Markiewicz, 2015: 145; wyróżnienie - K.D.-M.).

Z punktu widzenia analizy procedur normalizacyjnych w komunikacji linguistic hedges mają zatem funkcję normalizacyjną. Za ich pomocą zaznaczyć można stopień przynależności danego $x$ do obszaru normalności (zakładanego jako wspólny). Obszar ten powstaje (jest proponowany) za każdym razem na nowo wraz z ofertą komunikacyjną (wypowiedzią), w ramach której $x$ jest określane w taki sposób właśnie. Nie oznacza to jednak, że pole możliwych nawiązań konstruowane jest „zniczego”, lecz musi sięopieraćna przesłankach podzielanych przez potencjalnych interlokutorów. Tylko na podstawie takich wspólnych przesłanek nawiązywalność może być w ogóle dopiero generowana, a kiedy oferta komunikacyjna pozbawiona

16 Przy tej (ostatniej) perspektywie pozostaje się, także omawiając szersze zagadnienie nieokreśloności w językoznawstwie, gdzie rozróżnia się „nieokreśloność referencjalną, która wiąże się z brakiem odniesienia do konkretnych obiektów rzeczywistości” od związanej „z niepewnością osoby mówiącej” (Doboszyńska-Markiewicz, 2015: 144, przypis 6, na podstawie Arutjunova, 1998: 814nn). Kwestia (nie)określoności jest przy tym (inaczej niż nieostrość) traktowana jako podstawowa kategoria, niezależna od jej leksykalnej manifestacji: „Jak czytamy w pracy S. Karolaka [...], nie jest to kategoria przysługująca tylko językom, które mają jej specjalne (leksykalne lub pozycyjne) wykładniki. Rodzajnik określony »jest tylko dodatkowym znakiem reflektującym określoność", a kategoria określoności »jest równoznaczna z intensjonalną zupełnością/niezupełnością nazw, która wyznacza ich zupełną lub niezupełną ekstensjęı"" (Doboszyńska-Markiewicz, 2015: 144). 
jest odniesień, wtedy mamy do czynienia z brakiem nawiązywalności - wprowadzone przez wypowiedź przesłanki okazują się niewiabilne. Pochodzące z biologii ewolucyjnej pojęcie wiabilności (patrz von Glasersfeld, 1998) w ramach teorii komunikacji i badań normalności oznacza:

Normalność jest dla komunikacji podobnie ogólną kategorią odniesienia, jak wiabilność w odniesieniu do systemowego ujęcia zjawisk na różnych poziomach rzeczywistości. [...] „Wiabilne są zatem koncepcje naukowe, obiekty medialne, sposoby i typy komunikacji, wiabilne są manifestacje systemów społecznych, organizmy, gatunki, systemy ekologiczne i środowiska. Kiedy coś jest wiabilne, wtedy funkcjonuje; kiedy zmieniają się warunki (lub sami je zmieniliśmy), coś innego staje się wiabilne. Innymi słowy: w każdym momencie coś innego może być oczywiste. Ale zawsze coś jest oczywiste. Nie przywiązujmy się więc do tego, co jest oczywiste, lecz tylko do oczywistości. Która się pojawia i zostaje zastąpiona inną. Jak widać, konsekwencje takiego stanowiska posiadają również implikacje etyczne i stosowane mogą być również w tak zwanym życiu codziennym" (Fleischer, 2013: 175-176; Siemes, 2015: 72).

Z jednej strony więc możliwych nawiązań jest (i powinno być) wiele, aby zagwarantować wiabilność i wyprodukować wysoką nawiązywalność, to znaczy duże prawdopodobieństwo nawiązania do danej oferty komunikacyjnej. Z drugiej strony gama ta musi być ograniczona, to znaczy wykazywać musi mniej niż nieskończonq liczbę możliwych nawiązań. Obydwa aspekty łącznie muszą być dane w stopniu wystarczającym dla zapewnienia toku komunikacji. Na ten niezbędny dla kontynuacji komunikacji warunek zwrócił uwagę już pod koniec XIX wieku logik i matematyk Gottlob Frege, oddzielając paradoksy logiki od fenomenów komunikacji:

Frege rozumiat jednak doskonale, że czym innym jest język logiki, a czym innym język potoczny (Alltagssprache). To właśnie ten filozof zauważył, że w języku naturalnym nieostrość znaczeń nie stanowi problemu, nie przeszkadza bowiem w komunikacji, dopóki jej uczestnicy wiążą z danym znakiem językowym wystarczająco podobne sensy.

[...]

Frege porównuje Alltagssprache do oka, zaś idealny język formalny do mikroskopu. Ten drugi jest specjalistycznym narzędziem, potrzebnym tylko nauce, niemającym zastosowania w życiu codziennym. Trudno jednak zarzucać oku, że nie widzi tego wszystkiego, co można zobaczyć przez mikroskop, tym bardziej że w codzienności oko ma przecież znacznie więcej zastosowań niż on (Frege, 1964: XI; za Doboszyńska-Markiewicz, 2015: 139-140 oraz przypis 3; zob. też: Frege, 1884). 
Dysponując wspólnym aspektem funkcjonalnym również lingustic hegdes mogą stanowić (pod tym kątem) spójny zbiór jednostek, mimo ich niejednorodności pod względem formalnym i semantycznym. Operację związaną z tym funkcjonalnym wymiarem można określić jako odwołanie do „bezpiecznego z różnych względów komunikacyjnych wzorca” (Doboszyńska-Markiewicz, 2015: 150), klasyfikując dane $x$ jako $y$, ale zaznaczając jednocześnie obszar niepewności tej klasyfikacji, na przykład przez zastosowanie określeń typu: „swego rodzaju”, „mniej więcej” itp. („osłabiacze” - deintensyfikatory, detensifiers - Myers, 1996, za Doboszyńska-Markiewicz, 2015: 145).

Na funkcjonalny oraz zabiegowy charakter hedges wskazuje także to, że obszar (nie)pewności równie dobrze może być konstruowany za pomocą przeciwnego, ale strukturalnie identycznego zabiegu, to znaczy na podstawie twierdzenia, że coś jest „typowe”, „prawdziwe”, „rzeczywiście” itd. („wzmacniacze”, intensifiers). Zmienia się przy tym jedynie pojawiający się „na powierzchni” kształt konkretnej wypowiedzi, natomiast forma zabiegu, schemat postępowania, strategia komunikacyjna pozostają takie same, to mówienie o obiekcie komunikacji $x /$ odniesienie do $x$, bazujące na przesłance, że istnieje prototyp (typowe $x$ ) oraz że obiekty komunikacji są stopniowalne w odniesieniu do zakładanego obszaru normalności (z prototypem w centrum) i odpowiadają mniej lub bardziej (aż po prawdziwą, rzeczywistą, (proto)typową wersję) jego charakterystyce, funkcjonującej jako system przesłanek. Także obszar (nie)pewności stanowi więc dwustronny czy dwuwymiarowy koncept sytuujący się w tle ofert komunikacyjnych. Jeśli chodzi o inne jeszcze implikacje nieostrości w komunikacji, które można na poziomie teoretycznym zrekonstruować, Doboszyńska-Markiewicz $(2015: 143,149)$ mówi o wynikającej z tego zabiegu wiarygodności, co zakłada aktualizację modelu typu nadawca - odbiorca w tle. W terminologii systemowej teorii komunikacji natomiast postuluje się zabiegi gwarantujące nawiązywalność już w obrębie samego komunikatu. Wtedy proces negocjowania znaczeń modelować i wyjaśniać można w szerszej niż „dwuosobowa” i linearnej perspektywie. Dopiero bowiem przez nawiązywalność powstaje w ogóle możliwość powielania (takich, a nie innych) komunikacji, to znaczy generowane są obszary normalności, które z jednej strony są elastyczne (ich granice podlegają ciągłej negocjacji), a z drugiej zdefiniowane są w wystarczającej dla kontynuacji komunikacji mierze, czyli w ten sposób, że w ogóle można nawiązać do „czegoś”.

Omawiając zagadnienie nieostrości w komunikacji, koniecznie uwzględnić należy również procesualny charakter tego zagadnienia. Pojawianie się nieostrości nie jest kwestią przypadku i nie da się jej sprowadzić do niechcący produkowanych niedokładności czy błędów, co trzeba by twierdzić, zajmując perspektywę normatywistyczną (protonormalizmu - Jürgen Link). Zajmując się funkcjami nieostrości 
w komunikacji, nie możemy również ujmowaćjej w sposób wartościujący lub moralizujący, jako coś gorszego i niedoskonałego, jako niechlujność ze strony producenta wypowiedzi, jako brak kompetencji językowych interlokutorów lub (w wypadku wypowiedzi niejęzykowych, np. w fotografii) w kategoriach braku wiedzy technicznej. Nieadekwatne jest również rozpatrywanie nieostrości z uwagi na motywacje i cele (np. manipulacja lub poprawienie wiarygodności wypowiedzi), gdyż oznaczatoby to, że bylibyśmy w stanie komunikować również, nie stosując jej, to znaczy generować całkowicie „ostre”, w stu procentach dokładne, dookreślone wypowiedzi. Tę możliwość oferuje matematyka i jej system liczb, lecz nie komunikacja ${ }^{17}$.

Jednak tego typu stanowiska nie pozwalają na wyjaśnienie zjawiska z perspektywy zewnątrzsystemowej. Stosując natomiast tę ostatnią, pojawia się ciekawe pytanie o to, skąd właściwie wiemy (uwzględniając, kim jest owo „my” w danym kontekście) lub na jakiej podstawie stwierdzamy, że coś zaczyna być lub jest nieostre (niewyraziste, niejasne...) oraz kto/co ustala granicę między tym, co uznawane jest za dokładne, ostre, wyraziste, a tym, co niedokładne, niejasne. Jednym z kryteriów ustalania tej (płynnej) granicy może być swego rodzaju dwustronna „wystarczalność”, czyli uznanie, że coś jest w wystarczającym (zadowalającym) stopniu dokładne, by móc w komunikacji funkcjonować i produkować nawiązywalność, a jednocześnie wystarczająco niedokładne, by produkować kolejne komunikacje.

Tylko na pierwszy rzut oka wydaje się to paradoksalnym zjawiskiem - im mniej dokładne coś jest, tym więcej trzeba/można o tym komunikować. Zasada ta działa jednak tylko do pewnego stopnia, gdyż coś, co „w ogóle niczym” nie jest i jest nieokreślone, nie jest w stanie funkcjonować jako umożliwiający nawiązania punkt odniesienia. Szczególnie korzystną strategią dla kontynuowania komunikacji zdaje się zatem być połączenie obydwu sprzecznych aspektów: z jednej strony odnoszenia się do czegoś, co już jest ustalone (co oznacza sytuowanie wypowiedzi w zakładanym obszarze normalności), a z drugiej strony pozostawienia otwartą kwestii, jak dokładnie wygląda relacja między obiektem odniesienia a wybranym obszarem normalności. To zawsze produkuje otwartość, gdyż kolejni interlokutorzy mogą zaproponować inne ujęcie tej relacji (i to nawet wtedy, kiedy w wypowiedzi coś ma normatywny charakter).

Tę dynamikę komunikacji można dość dobrze zaobserwować tam, gdzie z zasady ostry system opisu napotyka na system zasadniczo nieostry, na przykład w badaniach nad rolą liczb w komunikacji, która manifestuje się między innymi w prostym zabiegu podawania przybliżonych liczb (dookreśleń typu „okrągłe”, „około”, „do...”, „mniej/więcej” itp.) i wyposażania ich w „tolerancję nieostrości”. Przy stosunkowo

17 Nawet liczby w komunikacjach, to znaczy raz przejęte do komunikacji i stanowiące tylko element bardziej kompleksowych wypowiedzi językowych, tracą swoją, wpisaną w nie przez przesłanki systemu liczb, dokładność, stając się liczbami komunikacyjnymi, które można wyposażyć w dodatkowe elementy zaznaczające ich nieostrość (szerzej na temat zob. Siemes, 2009). 
małym nakładzie pracy generowany jest w ten sposób szeroki potencjał nawiązań: $z$ jednej strony nieostrość podawanych danych rozszerza trafność tego, co zostato powiedziane, $z$ drugiej zastosowanie liczb łączy wypowiedź z konceptem liczb oraz związaną z nim obietnicą jednoznaczności. Wypowiedź jest w ten sposób podwójnie zabezpieczana, i to za pomocą dwóch - właściwie sprzecznych - metod: markowania nieostrości oraz jednoznaczności (Siemes, 2009: 232).

W komunikacji zatem nie chodzi o dokładność (lub ostrość), lecz o to, aby zorganizować niedokładność/nieostrość w taki sposób, aby uruchomiła ona komunikację i dała podstawę do kolejnych nawiązań, oferując coś, co stanowi potencjalną podstawę dla perpetuowania komunikacji. Nieostrość w tym ujęciu nie jest wadq komunikacji, lecz jej warunkiem i początkiem. Świat bowiem nie jest ani określony, ani nieokreślony. Dopiero odnosząc się do niego w komunikacji, powstaje potrzeba określenia czegoś jako wyodrębnionego elementu i wtedy rozpoczynać można debaty o (nie)ostrości, niejasności, (nie)dokładności. W odróżnieniu od perspektywy inżynierskiej, logiki komputerowej itp. w komunikacji nie dążymy do ostatecznego, matematycznie precyzyjnego określania, podejmowania jednoznacznych i ostatecznych decyzji, czy coś jest $x$ lub $y$, czy oraz w jakim stopniu przyporządkować dany obiekt do tej lub innej klasy. W logice fuzzy taka decyzja w niektórych modelach jest co prawda przesuwana na dalszy plan lub skalowana, niemniej jednak pozostaje celem w takim sensie, że decyzja na temat decyzji (np. odłożenie na później) stanowi warunek wykonania kolejnych operacji. W komunikacji natomiast nie chodzi o podejmowanie decyzji, lecz o to, aby o nich mówić, o gamie możliwych w danej sytuacji decyzji oraz potencjalnym ich podejmowaniu, gdyż mówienie oznacza perpetuowanie komunikacji, podjęcie decyzji natomiast - jej koniec. Każdy standard (obszar normalności, pole semantyczne itd.) stabilizuje się w komunikacji tylko po to, aby ponownie podlegać komunikacyjnej negocjacji, jest opracowywany, aby - metaforycznie mówiąc - podlegać znowu rozwodnieniu. Dopiero odchylenie od standardu prowokuje dalsze komunikacje i utrzymuje proces negocjacji w toku.

Póki standard funkcjonuje w sposób niekwestionowany, mamy jedynie do czynienia z mechanicznym stosowaniem normy. Szerzej rzecz ujmując, szeregowanie, łączenie ze sobą kolejnych samopotwierdzających się komunikacji, których aspekt semantyczny staje się bezfunkcyjny (np. w ramach grup społecznych używających znaków jedynie w roli indeksu wskazującego na przynależność, ale bez systemu wartości czy ideologii w tle), oznacza, że „dochodzi do samozwrotności komunikacji. Ona sama nadal się odbywa (lub może odbywać), tyle że bez znaczeń" (Fleischer, 2019: 53). Jednocześnie standardy, a szerzej - możliwość nawiązania do zakładanych jako stałych, z góry ustalonych obszarów normalności, zabezpieczają komunikację 
przed ciągłym zacinaniem się jej we własnych procedurach, przed niekończącą się debatą na temat samych podstaw i warunków niezbędnych do rozpoczęcia komunikacji. Innymi słowy, niepewność, czyli ryzyko odrzucenia oferty komunikacyjnej (w terminologii teorii systemów: podwójna kontyngencja), może być opanowana przez wspólnie podzielane, milczące założenie, że operuje się na tej samej podstawie.

W tym kontekście ważnym czynnikiem staje się przypadek - dopiero nieobliczalność biegu rzeczy oraz brak możliwości całkowitego opanowania współzależności utrzymuje system w stanie dynamicznym, zachowując jego zdolność do zmiany i dopasowania się do (zawsze jakoś) zmieniających się warunków wewnętrznych i zewnętrznych ${ }^{18}$. Na to, że obchodzenie się z niejasnością stanowi specyficzną ludzka kompetencję, zwracają zresztą uwagę badacze z różnych dyscyplin naukowych. W psychologii jest ona między innymi dyskutowana w zakresie tolerancji sprzeczności (Ambiguitätstoleranz). Również w ramach logiki fuzzy jej konstatacja stanowi punkt odniesienia:

[...] as the complexity of a problem increases, the possibility of analyzing it in precise terms diminishes. [...] From this point of view, the capacity of a human brain to manipulate fuzzy concepts and non-quantitative sensory inputs may well be one of its most important assets (Zadeh, 1972: 132).

\section{Podsumowanie i operacjonalizacja - cele i pytania przewodnie dla (różnych) badań empirycznych}

Nieostrość stała się problemem i przedmiotem dyskusji w różnych dyscyplinach naukowych, jednak z perspektywy badań komunikacji i normalności poświęcono jej do tej pory mało uwagi, a z zaprezentowanych tu rozważań teoretycznych wynika, że odgrywa ona kluczową rolę. Aby problemem nieostrości w komunikacji móc zająć się analitycznie, należy rozróżnić między nieostrością jako problemem mierzenia oraz nieostrością jako warunkiem komunikacji. W zakresie dotyczącym pierwszej i drugiej rzeczywistości (fizyka, chemia, biologia - ogólnie nauki ścisłe nieostrość stanowi problem poznawczy. Natomiast w komunikacji (trzeciej rzeczywistości) nieostrość jest gwarantem jej kontynuacji, warunkiem perpetuowania procesu nawiązywania do ofert komunikacyjnych. Komunikacja nie tyle służy

18 Także z tego powodu nie powinniśmy przy negocjowaniu i organizowaniu kwestii społecznych polegać na algorytmach, ale te mimo to stają się aktualnie coraz częściej stosowanym elementem organizacji życia codziennego w kontekście wszechobecnych „rozwiązań” na obszarze tak zwanej sztucznej inteligencji. 
wynegocjowaniu (ustaleniu) przypisań znaczeń, ile negocjowaniu ich. Innymi słowy ${ }^{19}$, dla konstytuowania rzeczywistości społecznej, to znaczy w kontekście społeczno-komunikacyjnym, istotnym aspektem nie jest osiągnięcie ostatecznego wyniku, lecz procesualność, zmienność oraz negocjowalność społecznych „stanów rzeczy", ustalanie tego, co potem wspólnie uznajemy za taki stan. Stany takie muszą z jednej strony być akceptowane jako uzasadniona podstawa dla dalszych komunikacji, a z drugiej muszą podlegać w tym procesie ciągłej (re)negocjacji.

Ogólny problem badawczy można na tym tle zawrzeć w pytaniu o to, jaką rolę odgrywa oraz czemu służy nieostrość przy negocjacji znaczeń, traktowanej w teorii komunikacji jako podstawowy mechanizm napędowy komunikacji, służący generowaniu społeczeństwa (Fleischer, 2007).

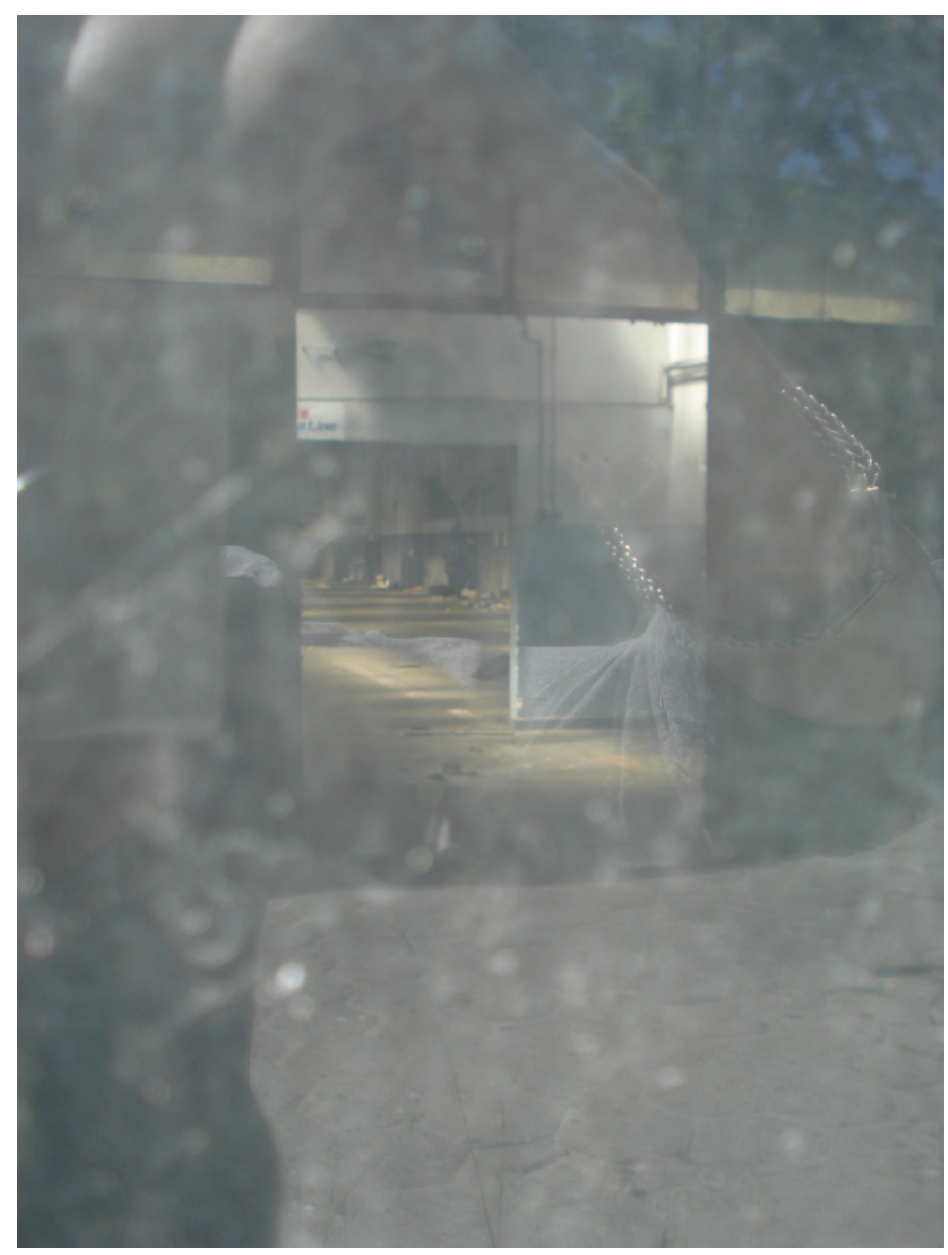

Ilustracja 3

Szukanie / mglistość

wyobraźni

/ szatnia / chcę tu być /

urbanizacja...

(fot. Annette Siemes)

Źródło: archiwum autorki.

19 Możliwość użycia takiego „innego” sformułowania wskazuje z kolei na ciągłą obecność nieostrości w komunikacji. 
Na podstawie dotychczasowych rozważań okazuje się bowiem, że nieostrość z perspektywy jej funkcjonalności w komunikacji raczej nie może stanowić elementu, który można do czegoś (zasadniczo ostrego) dodać lub od czegoś ująć. Nieostrość interesuje nas w tej perspektywie nie tylko jako słowo i „temat” na poziomie leksykalno-semantycznym, gdzie siłą rzeczy (lub siłą dualizmu) konstruowana jest na podstawie konceptualnego podziału „ostre/nieostre” lub na tle otwartej/nieskończonej w obie strony skali. W komunikacji ważną rolę odgrywa właśnie brak możliwości ostatecznego ograniczenia lub niwelowania nieostrości. Pytanie, czy jesteśmy w stanie dokładnie sprecyzować coś (ustalić jego granice), co z zasady jest niedokładne (i kategoryzowane jako nieostre), tylko na pierwszy rzut oka stanowi dylemat lub paradoks. Zajmowanie się nim tylko wtedy wydaje się przedsięwzięciem pozbawionym sensu, kiedy podejmujemy tego typu kwestie w kategoriach normatywnych, chcąc ujednoznaczniać znaczenia. W badaniach komunikacji natomiast chodzi o pokazanie funkcji takiej kategoryzacji (klasyfikacji czegoś jako nieostre) lub takich debat (dążących do dokładnego ustalania granic nieostrości).

$\mathrm{Na}$ tle szerszego problemu funkcjonalności pytania badawcze dotyczące semantyki i znaczenia komunikacyjnego ${ }^{20}$ słowa „nieostrość” stanowią pierwszy krok operacjonalizacji problemu dla szerszych analiz empirycznych. Celem natomiast jest wtedy określenie znaczenia komunikacyjnego tego słowa (lub podobnych) w ramach danego dyskursu, czyli 1) odkrycie naddatku znaczenia, który powstaje w komunikacji w efekcie pojawienia się nieostrości w danym kontekście (specjalistycznym, tematycznym, sytuacyjnym). Oznacza to też, że 2) przy rekonstrukcji i analizie semantyki chodzi równocześnie o badanie kategorii nieostrości jako obszaru odniesienia i konceptu sytuującego się w tle wypowiedzi.

Ad 1. Aspekty dotyczące semantyki i potencjalnego znaczenia komunikacyjnego możemy badać za pomocą metod ankietowych lub korpusowych, pytając: „jakie znaczenia przypisywane są nieostrości lub są z nią związane w przypadku dosłownych odniesień?”, „gdzie/kiedy nieostrość jest używana lub uznawana za środek stylistyczny, zabieg dla osiągnięcia danego efektu itp., a gdzie/kiedy klasyfikowana jest jako błąd lub wada?".

Ad 2. Ujmując rzecz z szerszej perspektywy, dodać można kolejne pytania: „W jakich kontekstach znaczeniowych oraz funkcyjnych pojawia się nieostrość jako kategoria komunikacji, zarówno jako konstrukt pojęciowy, jak i koncept i wielkość

20 Szerzej 0 znaczeniu komunikacyjnym zob. Fleischer, Siemes, Grech (2021: 21): „Znaczenie komunikacyjne to takie znaczenie, które obowiązuje zawsze tylko dla określonej formacji, stanowi o znaczeniu danego znaku (lub kompleksu znaków) dla tej konkretnej formacji, a odbiega od ogólnojęzykowego - nazwijmy je - znaczenia leksykalnego w specyficznym dla danej formacji względzie. Dla innej formacji ten sam środek znaku posiadać może inne znaczenie komunikacyjne, lecz to samo znaczenie leksykalne" [wyróżnienie - A.S.]. 
sfunkcjonalizowana (np. w ramach formułowania ocen, sądów aksjologicznych itp.)?” oraz ,jak jest w obydwu kontekstach (znaczeniowym oraz funkcyjnym) stosowana i (re)negocjowana?".

Jednym z wyzwań wynikających z tych pytań na etapie projektowania badań i doboru materiałów badawczych jest znalezienie, a następnie analiza również takich materiałów, w których samo słowo „nieostrość” (lub jego derywaty) eksplicytnie nie występują, ale w których koncept nieostrości spełnia swe funkcje „w tle” wypowiedzi, co z kolei można wydobyć i uwidocznić za pomocą odpowiedniej metody i techniki badawczej (np. eksperymentu, z elementami ankiety lub wywiadów jakościowych, metodą „głośnego myślenia” itp.).

Omówione na początku nieostre zdjęcia są o tyle ciekawym materiałem, że stanowią niewerbalne oferty komunikacyjne, którym cecha nieostrości niekoniecznie musi, ale może być przypisywana na poziomie wypowiedzi werbalnych, i który to materiał można wtedy wykorzystać w ramach eksperymentów, przedkładając go respondentom z możliwie otwartą prośbą o nawiązanie do niego. Pierwsze, pilotażowe badanie w tym zakresie jest w trakcie. W wersji eksploracyjnej zostało ono przeprowadzone na konferencji naukowej i polegało na (trzydziestosekundowym) wyświetlaniu serii zdjęć autorki z prośbą o zanotowanie tego, co przy każdym zdjęciu przychodzi oglądającym na myśl. Odpowiedzi okazały się na tyle ciekawe i różnorodne, że wyniki etapu eksploracyjnego wykorzystane zostały do opracowania scenariusza ostatecznego badania, modyfikując nieco techniczne i praktyczne aspekty procedury (liczba pokazanych zdjęć, czas ich pokazywania, zadane pytania itp.).

Na podstawie tak uzyskanych ewidencji i doświadczeń można w kolejnych badaniach wykorzystać też inny materiat - w zasadzie wszystko, co w procesie komunikacji może stanowić „surowiec” dla produkcji nawiązywalności. W grę wchodzą zatem zarówno „nieostre” wypowiedzi werbalne, jak i materiał wizualny lub dźwiękowy. Dodatkowe pytania badawcze mogą wtedy brzmieć: „co powoduje, że coś jest (może być) klasyfikowane (a) jako w ogóle »coś«, to znaczy jest identyfikowane jako oferta komunikacyjna oraz jako określony typ wypowiedzi (tekst pisany/mówiony, obraz, muzyka), (b) jako nieostre/niewyraziste $x$ w danym materiale (patrz a) oraz (c) po co nam taka klasyfikacja i konstatacja odchyleń od pewnych standardów?".

Badanie tych kwestii w proponowany tu sposób wymaga dużego zaangażowania i odpowiednich kompetencji oraz zainteresowania ze strony jego potencjalnych uczestników; tego typu scenariusz sensownie przeprowadzać można zatem raczej tylko w kręgach specjalistów danego obszaru (wśród badaczy, studentów odpowiednich specjalności, osób działających artystycznie w danej dziedzinie lub nią zainteresowanych itp.), jak miało to miejsce w badaniu eksploracyjnym. 


\section{Bibliografia}

Arutjunova N.D. (1998), Jazyk i mir čeloveka, Moskva: Jazyki russkoj kul'tury.

Bauer T. (2018), Die Vereindeutigung der Welt: Über den Verlust an Mehrdeutigkeit und Vielfalt, Ditzingen: Reclam.

Computerwissen (2017), So erzeugen Sie fotografisch korrekte Unschärfe, https://www.computerwissen.de/bildbearbeitung/photoshop-tutorials/artikel/so-erzeugen-sie-fotografisch-korrekte-unschaerfe.html (dostęp: 23.10.2019).

Doboszyńska-Markiewicz K. (2015), 0 jakby nieostrości i jej swego rodzaju operatorach (linguistic hedges) - uwagi wstępne „Linguistica Copernicana", nr 12, s. 137-155, http://dx.doi.org/10.12775/LinCop.2015.006

Fleischer M. (2007), Ogólna teoria komunikacji, Wrocław: Wydawnictwo Uniwersytetu Wrocławskiego.

Fleischer M. (2013), Notatki, Kraków: Wydawnictwo Libron.

Fleischer M. (2018), Notatki 3, Kraków: Wydawnictwo Libron.

Fleischer M. (2019), Design informacji ijej algorytmy, Kraków: Wydawnictwo Libron.

Fleischer M. (2020), Desemantyzacja komunikacji ijej indeksalizacja, Kraków: AT Wydawnictwo, Wydawnictwo Libron.

Fleischer M., Siemes A. (2020), Świadomośc i przynależność subkulturowa wśród młodzieży, [w:] M. Grech, K. Lachowska, K. Olender, A. Siemes (red.), Badanie komunikacji/projektowanie komunikacji, t. 3, Kraków: Wydawnictwo Libron, s. 9-64.

Fleischer M., Siemes A., Grech M. (2021), Stabilność polskiej i niemieckiej symboliki kolektywnej, Wrocław-Kraków: Wydział Filologiczny Uniwersytetu Wrocławskiego, Wydawnictwo Libron.

Frege G. (1884), Die Grundlagen der Arithmetik: eine logisch-mathematische Untersuchung über den Begriff der Zahl, Breslau: Wilhelm Koebner.

Frege G. (1964), Begriffsschrift und andere Aufsätze, Darmstadt: Wissenschaftliche Buchgesellschaft.

Freitag S., Geierhos M., Asmani R., Haug J.I. (red.) (2018), Unschärfe - der Umgang mit fehlender Eindeutigkeit, Paderborn: Ferdinand Schöningh. Glasersfeld E. von (1998), Die Radikal-Konstruktivistische Wissenstheorie, „Ethik und Sozialwissenschaften”, vol. 9(4), s. 503-511.

Kluck N. (2014), Der Wert der Vagheit, Berlin: De Gruyter.

Kukołowicz T. (2018), Nieostrość pojeccia oryginalności w rozumowaniach z obszaru prawa autorskiego, praca doktorska napisana pod kierunkiem prof. dr. hab. Jacka Malinowskiego, Instytut Filozofi i Socjologii Polskiej Akademii Nauk, Warszawa, https://rcin.org.pl/ Content/69580/WA004_90861_PED-151_Kukolowicz-T-Nieostrosc_0000.pdf (dostęp: 30.09.2019).

Lakoff G. (1973), Hedges: A Study in Meaning Criteria and the Logic of Fuzzy Concepts, ,Journal of Philosophical Logic", vol. 2, s. 458-508.

Mulkar-Mehta R., Hobbs J., Hovy E. (2011), Granularity in Natural Language Discourse, https://www.researchgate.net/publication/228961900_Granularity_in_natural_language_discourse (dostęp: 21.04.2021).

Odrowąz-Sypniewska J. (2000), Zagadnienie nieostrości, Warszawa: Uniwersytet Warszawski, Wydział Filozofii i Socjologii.

Peirce Ch.S. (1931-1958), Collected Papers, vol. 1-6, Cambridge: Harvard University Press.

Pinkal M. (1980), Semantische Vagheit:Phaenomen und Theorien. Teil I, ,Linguistische Berichte", Heft 70, s. 1-26.

Pinkal M. (1991), Vagheit und Ambiguität, [w:] A. von Stechow, D. Wunderlich (red.), Semantik. Ein internationales Handbuch der zeitgenössischen Forschung, Berlin-New York: De Gruyter, s. 250-269.

Rieger B. (1996), Warum Fuzzy Linguistik? Überlegungen und Ansätze einer computerlinguistischen Neuorientierung, [w:] D. Krallmann, H.W. Schmitz (red.), Vorträge des Internationalen Gerold-Ungeheuer-Symposium, Essen 1995, Münster: Nodus Wissenschaftsverlag, https:/www.uni-trier.de/fileadmin/fb2/LDV/Rieger/Publikationen/Aufsaetze/98/essen95.pdf (dostęp: 3.10.2019).

Siemes A. (2009), Zahlen in Medienangeboten. Eine Studie zur Konstitution und Funktion medialer Zahlenwirklichkeiten, Oberhausen: Athena.

Siemes A. (2013), Normalność w komunikacjach - jej negocjowanie i badanie. Na materiale komentarzy dotyczących architektury domów mieszkalnych, Łódź: Wydawnictwo Primum Verbum.

Siemes A. (2015), Normalnośćz perspektywy obserwatora - diagnoza, Łódź: Wydawnictwo Primum Verbum.

Siemes A. (2020), Transformation design w kontekście projektowania komunikacji i badań normalności, Kraków: Wydawnictwo Libron.

Tenbrink T. (2020), Cognitive Discourse Analysis. An Introduction, Cambridge: Cambridge University Press.

Topolińska Z. (1976), Wyznaczoność (tj. charakterystyka referencyjna) grupy imiennej w tekście polskim. l: Uwagi ogólne; grupa imienna jako argument scharakteryzowany, "Polonica”, nr 2, s. 33-72.

Ullrich W. (2002), Die Geschichte der Unschärfe, Berlin: Verlag Klaus Wagenbach.

Wierzbicka A. (1999), Język - umysł - kultura, Warszawa: Wydawnictwo Naukowe PWN.

Zadeh L.A. (1972), Fuzzy Languages and their Relation to Human and Machine Intelligence, [w:] M. Marois (red.), Man and Computer, Basel: Karger, s. 130-165. 